\title{
The Philosophy of Sophie, Electress of Hanover
}

\author{
LLOYD STRICKLAND
}

In philosophical circles, Electress Sophie of Hanover (1630_-1714) is targely-known mainly as the friend, patron, and correspondent of Leibniz. While many scholars acknowledge Sophie's interest in philosophy, some also claim that Sophie dabbled in philosophy herself, but did not do so either seriously or competently. In this paper I show that such a view is incorrect, and that Sophie did make interesting philosophical contributions of her own, principally concerning the nature of mind and thought.

In recent years there has been explosion of interest in the philosophical thought of women in the early modern period. This heightened interest has led to a great deal of scholarship on six thinkers in particular, namely: Princess Elisabeth of Bohemia, Margaret Cavendish, Anne Conway, Mary Astell, Damaris Masham ${ }_{2}$ and Catharine Trotter. It is perhaps not surprising that attention has focused on these thinkers, given that all bar one wrote at least one philosophical book, the exception being Princess Elisabeth, who restricted her philosophical writing to her correspondence with Descartes. But even though the the attention of modern scholars, there were other women who made philosophical contributions in the early modern period. This paper is concerned with one of these othersElectress Sophie of Hanover (1630-1714).

Nowadays Sophie is best known as the German princess who was almost Queen of Great Britain. In March 1701, an act of Parliament (the "Act of Settlement") named Sophie as Queen Anne's successor to the throne, barring any further issue from Anne. As she was almost 35 -thirty-five years older than Anne, Sophie suspected that she would not live long enough to inherit the crown, a suspicion which that proved to be correct: she died on 8 June 8, 1714, a little less than two months earlier than Anne (who died on 1-August 1, 1714). Ultimately, it was Sophie's son, Georg Ludwig, who ascended the throne: following the death of Anne, he became King George I of Great Britain, the first of the Hanoverian line which that ruled Britain for 123 years.

In philosophical circles, Sophie is targely known mainly as the friend, patron ${ }_{2}$ and correspondent of Leibniz, who was employed by the court of Hanover. Although Leibniz and Sophie met often, both professionally and socially, they still corresponded regularly, and around 600 items of their correspondence survive today (this figure is inclusive of drafts and other variants). $<1>$ One writer remarks that "Their... . . correspondence covers all possible subjects." $<2>$ And it is indeed broad in extent; for example, some of the topics that came up in the correspondence were a man who had a sex change (Leibniz 1923_-, XIV-vol. 14, 8-9), whether the $18^{\text {th }}$-eighteenth century would begin in 1700 or 1701 (Leibniz 1923-, XVI-vol. $16,75),<3>$ and whether a large tooth dug up in Brunswick constituted evidence for the 
former existence of giants (Leibniz 1923-1923-, VII-vol. 8, 30). Other themes of the correspondence were, as one would expect, connected with the social and political events of the day, the Hanoverian succession especially. There was also much exchanging of news, such as births, deaths, and marriages, details of visitors, journeys undertaken, acquaintances made, and so on. Another popular topic was philosophy, discussed in 15 fifteen of the surviving letters from Sophie's side of the correspondence, and 34thirty-four from Leibniz's side. Moreover, these 15 -fifteen letters seem to represent the extent of Sophie's philosophical writing; although she did occasionally write about philosophy to her niece and one of her sisters, as we shall see in the next section, such writings appear to have been straightforward reports of philosophical ideas she had been told in person by Leibniz or Francis Mercury van Helmont, whereas in her correspondence with Leibniz, Sophie engaged in philosophical discussion proper. In choosing to discuss philosophy only in her correspondence with Leibniz, Sophie took after her sister, Princess Elisabeth of Bohemia, who enly-discussed philosophy only in her correspondence with Descartes, as mentioned above. Unlike Elisabeth, however, Sophie gets very little attention in the literature on early modern thinkers, and even in the literature on women philosophers of that $\underline{d t h i s}$ period. $<4>$ Much of what she does get merely repeats the point that she was the friend, patron $_{2}$ and correspondent of Leibniz, though it is often noted that she had an interest in philosophy too. $<5>$ However, $_{2}$ scholars disagree about the extent of this interest, with most considering it to have been a-passive-interest, i.e.that is, that Sophie was happy to read philosophy, and to encourage Leibniz to write about it to her, but little more than that. Others claim that Sophie did dabble in philosophy herself, but did not do so either seriously or competently. If either interpretation is true, it would be difficult to quibble with the lack of attention that Sophie has received from historians of philosophy, and specifically from those interested in the philosophical contributions made by women in the early modern period. However ${ }_{2} I$ believe that neither interpretation does Sophie justice, ${ }_{2}$, and the aim of this paper is to show that Sophie is deserving of more scholarly attention than she has heretofore received.

\section{SOPHIE AND PHILOSOPHY}

As previously noted, it is a commen claim by those who write about Sophie commonly claim that she had an interest in philosophy. The following remarks by Adolphus Ward are fairly typical:

Beyond a doubt, Sophia was distinguished by an intellectual curiosity that was still uncommon, though much less so than is often supposed, among the women of her age. .... . . She certainly had a liking for moral theology and philosophy, which were, in general, more in the way of the ladies of the period than the historical sciences. (Ward 1903, 191-923)

Jacqueline Broad tells us that Sophie "expressed an interest in philosophy" and "was extremely curious about intellectual matters, and encouraged the philosophical interests of her daughter, Sophie-Charlotte" (Broad 2002, 16 \& and 126-27). John Toland, who met Sophie in 1701 and 1702, has this to say of her: "She has bin long admir'd by all the Learned World, as a Woman of incomparable Knowledge in Divinity, Philosophy, History, and the Subjects of all sorts of Books, of which she has read a prodigious quantity" (Toland 1705, $677_{2}-$ SSee also Toland 1704, preface, ${ }_{2}$ \$7). Such remarks give the impression that Sophie's interest in philosophy was restricted to reading philosophical works and encouraging such activities in others. It is certainly true that Sophie did such things. We know, for example, 
that she read works like The DAtivine $\underline{B}$ being, $<6>$ Treatise on $\underline{H}$ thell, $<7>$ The Aart of $\underline{K}$ knowing Men, $<8>$ Boëthius's The Ceonsolation of Pphilosophy, $<9>$ and Antony Collins's $A$ Dtiscourse of Ffree-thinking. $<10>$ We know that Sophie liked to hear and read Leibniz's philosophical views, and his thoughts on the views of others. And-Wwe also know that Sophie sent details of some of Leibniz's views, as well as those of another thinker, Francis Mercury van Helmont, to her sister, Louise Hollandine, $<11>$-and her niece, Elisabeth Charlotte, Duchess of Orléans. $<12>$ If keeping abreast of the philosophy of others and encouraging others to do the same was the extent of Sophie's involvement with philosophy, then it would be correct to say that her interest in philosophy was generally a-passive-ene. But there is more. Some scholars note that Leibniz and Sophie discussed a number of philosophical and theological issues face to face. $<13>$ From Leibniz's side of the correspondence we can determine that such issues included proofs for God's existence, $<14>$ ethics, $<15>$ justice, $<16>$ purgatory, $<17>$ the existence and nature of unities/monads $<18>$ and so on. Unfortunately there are no records of most of these discussions, so exactly what exactly-Sophie contributed to them is impossible to determine. Leibniz did make a record of one such discussion - a short document entitled (by Leibniz) "Summary of what I said in a conversation with Madam the Electress of Brunswick-Lüneberg, in Hanover $29 X^{\text {br }} 1692$ " (Leibniz 1923-1923-, IX vol. 9, 14-16) - but, as the title suggests, it records only Leibniz's contribution to the conversation. Sophie's input, if there was any, is unknown.

Now-Tef course the fact that Sophie had philosophical discussions with Leibniz does not, of course, in itself- demonstrate that those scholars who have treated her as no more than a minor footnote in the history of philosophy (and the history of women's philosophy) were wrong to do so, especially since we have no idea of what or how much Sophie contributed to these discussions. But-Ceontrary to common belief, however, Sophie's involvement with philosophy extended beyond reading it, encouraging others to read it, and discussing it personally with Leibniz. An examination of her correspondence with Leibniz reveals that she herself engaged in philosophy from time to time too, stating her opinions and proffering arguments for them. $<19>$ However, the few scholars who have noted this are generally dismissive of Sophie's efforts. For example, F. E. Baily insinuates that Sophie's attitude towardstoward philosophy was less than serious:

A perusal of this correspondence leaves the reader with the impression that Sophia looked upon religion and philosophy in the abstract as the mental equivalent of a physical daily dozen exercises. She was neither deeply religious nor deeply philosophical but she was an epistolary chatterbox, and philosophy and religion were two of Leibniz' pet subjects. (Baily 1938, 119)

Other commentators state, explicitly or otherwise, that Sophie's philosophical abilities were very limited, citing some of Sophie's remarks thich that suggest that she had difficulty grasping basic philosophical ideas. For example, Beatrice H. Zedler writes that "Leibniz tried to show Sophie that thought and souls cannot be material, but Sophie will later say that she does not understand what is meant by 'thought' and by 'immaterial,' adding, 'I confess that surpasses me, perhaps because I do not comprehend the terms well enough...... to be able to penetrate to the truth"' (Zedler 1989, 49; -Cf.compare Broad 2002, 135). The passage Zedler has in mind is this one, from Sophie's letter to Leibniz of 27-November 27, 1702:

I do not understand very well what thought is, and how the immaterial is passive, for I do not know what the immaterial is nor how the material-active forms a body with the immaterial. I confess that this is beyond me. Perhaps I do not understand the 
terms of art well enough to be able to penetrate to the truth of the matter. (Klopp 1873, V世-vol. 8, 401- $\underline{02}$. All translations in this paper are my own.)

Zedler's partial quotation of this passage strongly suggests that Sophie was utterly out of her depth when it came to philosophy, as she struggled to grasp the sort of relatively simple concepts central to philosophical debate. However, when this passage is considered in its entirety, such a reading is not so obvious. For what exactly is meant by the immaterial being passive, and the material-active forming a body with the immaterial? As with all things, of course, the context is important. In this case, the context is a paper or set of papers written by Jakob Heinrich von Fleming (1667_-1728), a Saxon nobleman who visited the court of Berlin in the fall of 1702. Unfortunately it is difficult to piece together Fleming's views with any precision as his writings from this time have since been lost. Probably the most enlightening exposition of Fleming's views appears in Leibniz's letter to Sophie of 18-November 18 , 1702. In that this letter, Leibniz explains that Fleming had written a paper

in which he says that the immaterial is active, and the material passive. And that an inferior activeness, having formed a body with its passiveness, is very often subject to another superior activeness, that in this way simple life forms a living body; but that a higher activeness, to which this living body serves as matter, forms an animal. And that the animal itself serves as matter with regard to the activeness which-that forms man. And that even man is like matter compared to the supreme activeness that is the divinity. (Klopp 1873, VII-vol. 8, 396-97)

One of the few things that is clear from this passage is that Fleming had developed a very abstruse metaphysics; another is that Leibniz expounds it in much too compressed a fashion to make its claims easily intelligible. There does exist another paper on Fleming's views, written by an unknown author and sent to Sophie sometime in late 1702, but it throws no more light on Fleming's doctrines than does Leibniz's exposition. $<20>$ In fact the anonymous author of this paper also had some difficulty in grasping Fleming's views: the paper begins with the author stating that it is not possible to come to a judgement about Fleming's philosophy without further clarification. However neither this paper nor Leibniz's letter of 18 -November 18 contains any mention of thought or "material actives," which were two of the things that flummoxed Sophie in Fleming's philosophy. It must therefore be the case that the source of Sophie's confusion was another paper, either by Fleming or by someone else writing about Fleming's views. This paper has unfortunately been lost, so there is no way of knowing how lucidly it discussed the terms Fleming used and the philosophy he developed. Without this paper, I cannot see that anyone is in a position to draw any conclusions about Sophie's philosophical abilities from the fact that she was unable, by her own admission, to understand the things discussed in it.

Another oft-cited reason for casting doubt on Sophie's philosophical competence is that apparently she apparently-could not understand Leibniz's doctrine of unities (i.e.that is, his doctrine of monads). $<21>$ On various occasions Sophie informs Leibniz that she cannot understand his demonstration regarding unities, $<22>$ that she still does not understand unities, $<23>$ and that she may have an insufficient understanding of them. $<24>$ Such remarks have been seized upon by a number of scholars as evidence that Sophie's philosophical aptitude was relatively poor. $<25>$ But as with the previous case, such a conclusion is shown to be somewhat hasty when the context of Sophie's remarks are is considered. If we conduct a thorough examination of Leibniz's letters to Sophie on the topic of unities, what we find is the same argument repeated time and again: there must be unities because there are 
multitudes, which can be nothing other than the aggregation of unities. Here is a typical sample of Leibniz's remarks on unities from his correspondence with Sophie:

Now it is evident that there could not be composites without simples, nor pluralities without unities. (Leibniz 1923, IX vol. 9, 14-16; Leibniz for to Sophie, 29-Dec. 29 , 1692/8Jan. $\underline{8}, 1693)$

unities are souls...... unities have no parts, otherwise they would be pluralities; but that which has no parts is indestructible. (Leibniz 1923-1923-, XII-vol. 13, 46-51; Leibniz for to Sophie, Oct. 1696)

because every multitude presupposes true unities, it is clear that these unities could not be made from matter, otherwise they would still be multitudes and certainly not true and pure unities, such as are ultimately needed to make a multitude from them. (Leibniz 1923-1923-, vol. 18, XVIII-113-14; Leibniz for-to Sophie, 12 June 12, 1700)

I [have] often said that souls are UNITIESunities, and that bodies are MULTITUDESmultitudes, that is, that the soul is a simple substance and that the body is an accumulation of several-multiple substances. (LBr.F 16, Bl. 52; Leibniz to Sophie, 31-Oct. 31, 1705) $<26>$

From all this it is clear enough that unities are simple (in that they lack parts), that they are souls, and that in aggregation they compose bodies (multitudes/pluralities). This last claim is somewhat puzzling, however, for how can an aggregate of souls give rise to a body? Leibniz does of course have an answer to this question (which involves treating material bodies as phenomenal), but nowhere in his correspondence with Sophie does he see fit to-divulge it. This means that, so far as Sophie could tell from what Leibniz had written on the subject, material things were quite literally composed of immaterial souls. Given the obvious difficulty inherent in that this view, it is perhaps not surprising that Sophie was so uncertain as to whether she had properly understood what a unity was supposed to be.

As it happens, Sophie's suspicion that she had misunderstood Leibniz's doctrine of unities was well-placed, as is clear from her concern about Leibniz's claim that there are many unities (in fact infinitely many). On one occasion she informed Leibniz that "one should not speak of unities where there are several of them," and in an attempt to understand his doctrine she resorted to interpreting a Leibnizian unity as the world-soul, "which one could, in my view, call a unity" (Klopp 1873, IX vol. 9, 77; Sophie to Leibniz, 21-Nov. 21, 1701). Sophie evidently considered "unity" to mean "unique," or at least to entail "uniqueness," which was not Leibniz's understanding at all. However, to construe a "unity" in the way Sophie did was not in any way out of step with the French of her day, since according to the 1694 edition of the Dictionnaire de L'Académie française, "unité" at the time meant "singularité" (647), which in turn meant "qualité de ce qui est singulier" (480), and "singulier" meant "unique" (480). The problem, I suspect, was that Leibniz had failed to inform Sophie that he was using the term "unité" in a technical, philosophical sense; without that important piece of information, Sophie's belief that he was using the term in its everyday sense seems far from censurable.

In fact Sophie was not alone in failing to grasp Leibniz's unities. The Duke of Orléans, son of Sophie's niece, the aforementioned Elisabeth Charlotte, also failed to do so, notably after reading one of Leibniz's letters to Sophie of 31-October 31, 1705.<27> After reading this letter, the Duke wrote some comments for Leibniz in which he construed the latter as 
advocating the existence of "soul unities" and "material unities" (Klopp 1873, KX vol. 9, 16970; The Duke of Orléans to Leibniz [21-February 21, 1706]). Not only did Leibniz not attempt to correct the Duke's misunderstanding, but in a subsequent letter to Sophie he also praised the Duke's "sublime mind" and frothed that the Duke "enters so well into the heart of the matter, and goes so much beyond what gave him occasion to discuss it" (Klopp 1873, IX vol. 9, 170; Leibniz to Sophie [Mar. 1706]). From thisat, one would be tempted to conclude that the Duke had in fact developed Leibniz's doctrine of unities rather than misunderstood it! In any case, the Duke's misconception of Leibniz's view is less a reflection of his insight and philosophical acumen than it is of Leibniz's unwillingness to provide (or his carelessness in not providing) sufficient information about his doctrine of unities to make that doctrine easily intelligible from the outset. $<28>$

It seems to me that Sophie's only failing in this matter is-was her honesty in admitting that she could not understand Leibniz's doctrine, which, I submit, was at best incompletely stated to her, and at worst misleadingly stated. Consequently, in neither this case- of Sophie's avowed inability to grasp Leibniz's unities, nor the one previously discussed, of Sophie's avowed inability to grasp Fleming's notions of immaterial and material-active, and so onetc., are there sufficient grounds to draw any negative conclusions about Sophie's philosophical abilities.

\section{SOPHIE AS PHILOSOPHER}

Having examined and undermined the popular misconceptions concerning Sophie's lack of philosophical understanding, it is time now to turn to some of Sophie's positive writings on philosophy. As noted earlier, Sophie only discussed philosophy in 15 -fifteen of her letters to Leibniz, but from these scant pickings we can determine that Sophie was a very independent thinker. It might be thought that given Leibniz's frequent access to Sophie, and his willingness to expound his doctrines to her both in person and in by letter, that Sophie would have emerged as one of Leibniz's disciples, as indeed was the case with her daughter, Sophie Charlotte. $<29>$ But the evidence suggests that Sophie was no blind follower of Leibniz. In fact it is interesting to note just how little influence Leibniz appears to have had on Sophie's philosophical opinions. Indeed, on a number of issues on which Sophie voices her opinion, she takes a view diametrically opposedite to to-Leibniz's. For instance, on the matter of optimism, of which Leibniz was a fervent and public supporter, Sophie has this to say:

if it had pleased God to go to the trouble of creating all at once all the men of merit that there are, and had spared men the trouble of generation, it seems to me that his work would have been more perfect. (Leibniz 1923, VI-vol. 6, 40-41; Sophie to Leibniz, 4/14-May 4/14, 1691)

Implicit here is Sophie's belief that many of the people created by God are not meritorious, and that such people detract from the goodness or perfection of the world. Consequently, by including the non-meritorious in his creation, God's work is less perfect than it otherwise might have been. This is, of course, a very common objection to optimism. $<30>$ By making it, Sophie clearly reveals herself to be at odds with Leibniz's view that God has created the most perfect of all possible worlds.

And on the thorny issue of whether God saves all or condemns some to eternal punishment, Sophie writes: 
I amused myself by reading a book about the island of Formosa where 18-eighteen children a year were sacrificed in order to please a single God. It is much more reasonable for us to think that the good Lord gave his [son] for us all. $<31>$

Leibniz himself was himself an advocate of the doctrine of eternal punishment, and consistently rejected the doctrine of universal salvation. $<32>$ Moreover, this was a view that he was happy to share with Sophie. $<33>$ So on the matters of optimism and universal salvation, Sophie adopted positions which that in all likelihood she knew to be contrary to those taken by Leibniz. But nowhere is the lack of Leibniz's influence more pronounced than in Sophie's position on the nature of the mind. As Foucher de Careil correctly reports, Sophie "was a materialist......., and it is known that Leibniz was unable to convert her to the idea of the immaterial soul" (Foucher de Careil 1876, 52). What led Sophie to reject the idea of an immaterial soul in favour of a materialist conception of the mind was her own reflection on the nature of mind and thought. In the course of this reflection, she developed several arguments in favour of a materialist understanding of the mind, and it is to these that I now turn.

Sophie's first two arguments for the materiality of the mind emerge from a debate she had with the Abbé of Loccum, Gerhard Wolter Molanus (1633_-1722), in late May or early June 1700. In the debate, Sophie argued for the materiality of the mind, while Molanus argued for its immateriality. Sophie subsequently asked Molanus to put down-his arguments down in writing, which he did, and Sophie then sent Molanus's paper to Leibniz together with a letter containing a summary of her own views and a request that Leibniz act as arbiter. The relevant portion of Sophie's letter, written on Z June 2, 1700, is the following:

I will ask you to think about the dispute that my son the Elector [Georg Ludwig] had on thoughts whichthat, against him [Molanus], my son the Elector maintained are material inasmuch as they are composed of things which that enter into us through the senses, and inasmuch as one cannot think of anything without making for oneself an idea of things which that one has seen, heard, or tasted, like a blind man who was asked how he imagined God and said "-like sugar."-- (Leibniz 1923-1923-, XVII vol. 18,91)

There are in fact two distinct arguments in this passage, though before we consider them, we need to address Sophie's statement that these arguments were in fact those of her son, Georg Ludwig (later George I of England). For whatever reason, this appears to be an embellishment on Sophie's part. Indeed, Molanus prepared (for Leibniz's benefit) his own report on his debate with Sophie, and this report makes no mention of the presence or input of Georg Ludwig, and instead identifies all the resistance to the conception of the mind as immaterial as coming from Sophie:

When our most serene Electress [Sophie] who, as you know, is never able to refrain from paradoxes, interrupted me during lunch recently, she provoked me to a discussion about the definition of the soul and its real distinction from an extended thing. She then asked me to write down my thoughts on this matter; I wrote them and sent them to her. The most serene Electress attacked them and did not even respond to my arguments, but multiplied questions, as she is in the habit of doing, $<34>$ some of which were irrelevant while others were very easy to answer. In the end, she said that she would make you be the arbiter of this dispute, and to that end would send my paper to you, which she has done I'm sure. (Leibniz 1923-1923, XVII-vol. 18, 696; Molanus to Leibniz, 4June 4, 1700) 
We can only speculate as to why Sophie would credit her son with authorship of the arguments mentioned in her letter of $Z$ June 2, 1700, but whatever the reason may have been,

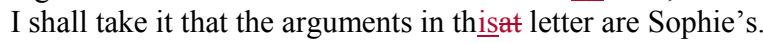

\section{ARGUMENT 1}

As mentioned above, Sophie's letter of Z June 2, 1700 contains two distinct arguments for the materiality of the mind. The first one is that "thoughts......-are material inasmuch as they are composed of things which that enter into us through the senses." The argument can be expressed thus:

Premise 1: All of our thoughts are composed of things which-that enter into us through the senses.

Premise 2: Only material things enter into us through the senses.

Conclusion: All of our thoughts are composed of material things.

The second premise I take to be suppressed in Sophie's account of her argument. The conclusion enly-says only that our thoughts are composed of material things, but if that this holds $\operatorname{good}_{2}$ then it is reasonable to infer that thoughts themselves must themselves-be material along with the minds in which they inhere.

Leibniz's response to this argument was $\underline{\text { is to say }}$

as for the material that enters into the brain through the senses, it is not this very material that enters into the soul, but the idea or representation of it, which is not a body, but a kind of effort or modified reaction. (Leibniz 1923-1923-, XVII-vol. 18, 113; Leibniz for to Sophie, 12 June 12, 1700)

Such a claim was very common in the early modern period, on account of the corpuscular hypothesis in vogue at the time. This hypothesis holds-held that material objects emit, er transmit, or reflect insensible material particles which-that are then picked up by a person's sense organs. Many corpuscularians believed that these particles then caused motion of the subtly material "animal spirits" running through the nerves, motion which that was subsequently carried to the animal spirits in the brain. And - Iit was the motion in the animal spirits there that was said to somehow produce a perception in the person's mind, with both the perception and the mind generally considered to be immaterial. $<35>$ Where this account gets hazy is in the detail of how motion of the material animal spirits in the brain could give rise to a perception or thought in the immaterial soul, as corpuscularians generally supposed it did.

Although Sophie does not offer any remarks on the corpuscular philosophy, she clearly accepts the first part of the account just discussed, namely that what enters into our senses is material. But that is where the agreement ends. For instead of claiming that the matter entering through the sense organs ultimately produces an immaterial perception, Sophie supposes that the perception it causes would itself be material in nature. Possibly her reason for thinking so was due to the concern, widespread in her day, that it was not clear exactly how a material cause could have an immaterial effect. Leibniz's response does nothing to assuage allay that concern. 


\section{ARGUMENT 2}

Sophie's second argument for the materiality of the mind in her letter of Z June 2, 1700 is this:

thoughts....... -are material... -inasmuch as one cannot think of anything without making for oneself an idea of things which that one has seen, heard ${ }_{2}$ or tasted, like a blind man who was asked how he imagined God and said "l'like sugar."'-

This argument requires a certain amount of unpacking. To begin withFirst, what exactly does Sophie mean by saying that we cannot think of anything without making ideas of things that we have sensed? In the French of the time (which was the language Sophie used when writing to Leibniz), the word "idée"- "idea"- had three meanings. It could mean an image (i.e.that is, a mental picture), a concept (i.e that is, a notion, a broad understanding), or a representation (i.e.that is, a mental stand-in for something, which includes but is not limited to images). We can work out which of these meanings Sophie has in mind by looking at her example of a blind man who can only think of God in terms of sugar. It is clear enough that in this example Sophie isn't thinking of images, as the blind man presumably couldn't visualize sugar even if he wanted to. Likewise, the blind man presumably wouldn't be thinking of the concept of sugar when he imagines God. Instead, what the blind man seems to be doing is trying to form a representation of God, and the closest he can get is sugar (and presumably it is the taste of sugar that the blind man thinks of, rather than its smell or how it feels to the touch). So from that this think-we can establish what Sophie means when she refers to "ideas"-she's thinking of representations, i.e.that is, mental stand-ins for whatever is being thought about. Her example of the blind man also gives us a further clue as to how her argument is supposed to work, because the blind man is imagining God. Assuming that Sophie considered God to be immaterial, which strikes me as likely, her example involves a blind man attempting to form a representation of an immaterial thing - God. The best he can do is think of the taste of sugar, but presumably if he wasn't blind he would think of something along the lines of the way God is traditionally depicted - as an old man with a beard, for instance. This certainly ties in with Sophie's claim that we cannot form an "idea," i.e.that is, a representation, of anything unless it's something we have sensed, something material.

Although none of this comes across as beingis especially controversial, neither does it obviously lead obviously to Sophie's conclusion that thoughts and minds are material in nature. So where does her argument go from here? The crucial thing, I think, is her view that we can form representations of material things alone. Sophie seems to take that this point as establishing her conclusion about the materiality of thought, which makes sense only by supposing that Sophie assumed the truth of a principle along the lines of: "that which represents is always of the same nature as what it can represent." If we feed such a principle back into Sophie's argument and treat it as a suppressed premise, which I think is reasonable, this is the resulting argument:

Premise 1: Our thoughts can represent material things alone.

Premise 2: That which represents is always of the same nature as what it can represent.

Conclusion: Therefore our thoughts are material.

The second premise itself, unstated but clearly assumed in Sophie's letter of Z June 2, 1700 , is undoubtedly inspired by or derived from the principle, in eurreneycommon with 
many Greek, medieval ${ }_{2}$ and renaissance thinkers, that "like is known by like," or at least from something very similar. Interestingly, this principle has been used throughout the history of philosophy to guarantee the immateriality of what is known by or represented in the mind. $<36>$ For as the mind is immaterial (according to many Greek, medieval, and renaissance thinkers), and like is known by like, consequently that which is known by or represented in the mind (usually taken to be forms or species) must be immaterial too. With her variation of the principle that "like is known by like," Sophie seems to turn this argument on its head by wresting out the conclusion that the mind must be material because it can represent material things alone.

It is interesting to note Molanus' $\underline{s}$ response to Sophie's second argument:

[this argument states that] it is impossible to think of something without forming a corporeal idea of it. For example, if one thinks of an angel, one imagines a boy who has wings; if one thinks of God, one imagines an old man with a long ${ }_{2}$ and-grey beard. I reply that if the majority of men form ideas like these it is because we are accustomed from our youth to having only corporeal things represented in our imagination. Nevertheless, when I think of God, I leave behind the images by which we are accustomed to represent him as ideas that are not only false, but also contradictory, and I consider God as a spiritual being which that has no dependence at all on any other being, or as a being possessing all the perfections. (Leibniz 1923 1923-, XVIII-vol. 18, 95; Molanus for to Sophie, June 1700)

What is striking about Molanus's reply is that it completely misses the point. His attack is focused on premise \#1 in the argument as I have constructed it above. Molanus evidently construes this premise as claiming that human minds cannot think at all except in terms of ideas of corporeal (i.e.that is, material) things. Undoubtedly, what leads Molanus to construe it this way is are the various meanings of the French word "idée," which as I noted earlier can mean an image, a concept, or a representation. When faced with Sophie's statement that "one cannot think of anything without making for oneself an idea of things which that one has seen, heard, or tasted," Molanus apparently construed the word "idea" in its broadest possible sense, as covering all three of its possible meanings. Consequently Molanus took Sophie to be saying that we cannot generate an image, or form a concept; or a representation, of anything other than material things. As such, he had little difficulty in finding a counterexample, namely that humans can form a concept of God, who is an immaterial thing. But as it turns out ${ }_{2}$ this is beside the point, for as I have noted above, Sophie uses the term "idea" only in its sense of "representation"; her claim is that our mental representations can only ever be of material things. Consequently, Sophie could happily accept Molanus's point that we can form an idea (understood as a concept) of an immaterial thing, while continuing to hold fast to her point that we can enly-form an idea (understood as a representation) only of material things.

\section{ARGUMENT 3}

Sophie's third argument for the materiality of the mind is to be found in her letter to Leibniz of 21 -November 21, 1701. The relevant passage is this one:

I am not entirely persuaded that thoughts do not occupy place, since; for I find my imagination so full that I remember the past and that Hyet have no more room for the present, in which I even forget what people look like. It therefore has to be that 
something material wears out or fills up, which produces the memory and which forms the ideas. (Leibniz 1923-1923-, XX-vol. 20, 77)

To understand this argument, we need to remind ourselves that in Sophie's day it was very common to think of the mind as a sort of cabinet, a container of thoughts, $<37>$ which is precisely the conception of the mind that Sophie appears to assume. I take this to be so from Sophie's remarks about the imagination being "full," having "no more room" for new memories, and that something material "fills up." It might be thought that her remark that "something material wears out" is at odds with the cabinet view of the mind I have attributed to her, but I doubt that it is simply because a material cabinet, which is what I think Sophie essentially took the mind to be, could wear out just as it could fill up (either of which would reduce its capacity). If Sophie's remark that "something material wears out" is thought to be inconsistent with the cabinet model of the mind, then the only other obvious way of interpreting it, to my mind, is as a reference to a wetware model of the mind, where mental processes and functions are thought to be embedded or implemented in the structures of the brain. But it stretches credibility to think that Sophie held such a modern view.

It seems reasonable to suppose, then, that Sophie conceived the mind as a cabinet or container. Now what Sophie does is highlight the fact that the human mind has a limited capacity, as there are only so many memories and ideas that it can hold. This leads her to suppose that the mental cabinet must be material in nature. Her reasoning here is presumably something like this: suppose that the mind is a material container and the ideas and memories it contains are material too. This would mean that there is only a certain amount of space in the mind, and as each idea and memory takes up some of the available space, we couldn't just keep adding them ad infinitum, as eventually a point would be reached where there is no more room in the mental cabinet to add any more. So if we think of the mind as a material container, then it's clear why it has the limited capacity it does. But if the mind were an immaterial container, then it is not at all obvious why it should even have a capacity. After all, the notion of a capacity, i.e. that is, a limit to how much a thing can contain within itself, is very much a material notion, as it trades on the idea of space and things which that occupy space. This, I think, is the thrust of Sophie's argument.

To my mind, what-Sophie's argument does is-presents the materialist hypothesis as the best explanation of certain mental phenomena, like forgetfulness. Given the basic assumption that the mind is a container of thoughts, which Sophie held, her argument appears to have some merit. Leibniz's response to this argument was -is to appeal to his theory of preestablished harmony, which in its popular form holds there to be a parallelism between events in the (immaterial) mind and the (material) body, without there being any interaction or direct causation between them. Hence he tells Sophie:

Regarding the soul's thoughts, as they must represent what happens in the body they could not be distinct when the traces in the brain are confused. So it is not necessary that thoughts have a physical location in order to be confused. (Leibniz 1923-1923-, XX-vol. 20,85)

Broadly speaking, Leibniz's point is that the states of soul and brain mirror or represent each other, so that what happens in the brain is represented in the soul, and vice versa. A consequence of this, of course, is that when the brain deteriorates, as it does with age, the soul experiences a corresponding deterioration in abilities which that parallels but is not caused by the deterioration of the brain. Leibniz perhaps does enough to show that the existence of certain mental phenomena like forgetfulness are consistent with his own theory of pre-established harmony, but he does nothing to show that his immaterial conception of 
the mind is preferable to Sophie's materialistic one. In fact Leibniz's response is far from satisfactory for another reason. As is well known, Leibniz believed that his theory of preestablished harmony "gives a wonderful idea of .......-the perfection of God's works" (Strickland 2006, 75) and admirably demonstrates the extent of God's wisdom and power (the attributes which that conceived and effected such a scheme). But Sophie could easily retort that Leibniz's theory is in fact disadvantageous to creatures endowed with minds, for, by making mental events parallel brain events and vice versa, God has ensured that any deterioration in key parts of the brain must go hand in hand with a deterioration in the mind's abilities, even though the mind itself has not deteriorated in any way (which it couldn't for Leibniz, given his belief that it is an immaterial—and hence indestructible—soul). Leibniz's theory may well highlight God's skills as an artisan, but it does so by allowing the corrosion of mental abilities even when there is and can be no corrosion in the immaterial mind proper. This anomaly is, I should think, an unfortunate corollary of the pre-established harmony, and one which that his theory would struggle to explain away.

\section{CONCLUSION}

On the whole, Sophie's arguments hold up well to the objections raised against them by Molanus and Leibniz, and when placed in their proper context can be seen as respectable and original contributions to the early modern debate about the ontological status of the mind. Moreover, in arguing for a materialist conception of the mind, a hypothesis widely considered to be unfashionable and even heretical in her own day, and in defending it against the objections of Leibniz and Molanus, Sophie reveals herself to be an independently_minded thinker prepared to follow her own philosophical instincts, undeterred by the concerns of others. For these reasons alone, I submit that Sophie deserves more sympathetic attention from scholars than she has heretofore received, and also a more prominent place in the history of philosophy than is given to those who are merely friends of great thinkers like Leibniz, or those who merely have a merely passive interest in philosophy.

\section{NOTES}

I would like to thank Stuart Brown, Daniel J. Cook, and two anonymous Hypatia referees for their helpful comments on an earlier draft of this paper. I would also like to thank Vernon Pratt for helpful discussions on some of the topics in this paper.

1. The bulk of these are available in Klopp 1873, vols. VII-7-_ IX9, and in Leibniz 1923--, vols. IV $\underline{4-X X 20 .}$.

2. Dirk van der Cruysse. See Sophie de Hanovre 1990, 15. Ef.Compare Foucher de Careil $1876,10$.

3. The issue of when the $18^{\text {th }}$-eighteenth century would begin was hotly debated at the time. See Weber 1999,15 . Leibniz correctly noted that the $18^{\text {th }}$-eighteenth century would begin in 1701 .

4. In one large volume on the history of women philosophers, for instance, Sophie gets only a single, passing mention, as someone who may have had a conversation with George Burnet about Catharine Trotter's Defence of Locke. See Waithe 1995, 123.

5. See, for example, - Ogilvie 1986, 166; Kersey 1989, 189-90; Garber and Ayers 1998, vol. 2, 1464; Broad; 2002; Garber and Ayers 1998, II 1464; Kersey 1989, 189 90; Ogilvie $1986,166$. 
6. Buchius 1694. See Leibniz 1923-1923-, Xvol. 10, 68.

7. Anon. 1694. This book was a Dutch translation of some or all of Richardson 1657. See Leibniz 1923-1923-, Xvol. 10, 68.

8. des Bans 1702. See Foucher de Careil 1854, 132.

9. Boëthius 1697. See Leibniz 1923-1923-, XIV vol. 14, 4.

10. Collins 1713. See Klopp 1873, IX-vol. 9, 393.

11. Kemble 1857, 461- $\underline{6} 2$.

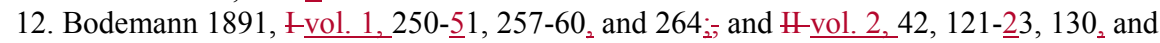
160.

13. E.g.For example Mates 1986, 26; Ross 1990, 61.

14. Leibniz 1923-1923-, IX vol. 9, 14-16.

15. Leibniz 1923-1923-, XIV vol. 14, 54-60.

16. Klopp 1877, X-vol. 10, 212-13.

17. Leibniz 1923-1923-, X-vol. 10, 89-90.

18. Leibniz 1923-1923-, IX vol. 9, 14-16.

19. Some scholars state that Sophie made comments on Leibniz's views, which is true, although such a claim does not adequately capture Sophie's involvement with philosophy. See Garber and Ayers 1998, \#vol. 2, 1464; Fara 2004, 146.

20. See the manuscript held in the Gottfried Wilhelm Leibniz BibliothekNiedersächsische Landesbibliothek, Hanover, under the shelf mark LBr.F 27, Bl. 171-2.

21. Leibniz in fact enly uses the word "monad" only once throughout his entire correspondence with Sophie, in a paper written on 12 June 12, 1700. See Leibniz 1923-1923, XVIIIvol. 18, 114.

22. Leibniz 1923-1923-, vol. 18, XVII-119-20; Sophie to Leibniz, 16-June 16, 1700.

23. Leibniz 1923-1923-, vol. XX 20,61; Sophie to Leibniz, 9-Nov. 9, 1701.

24. Leibniz 1923-1923-, vol. XX 20, 77; Sophie to Leibniz, 21-Nov. 21, 1701.

25. See, for example, Foucher de Careil 1876, 15; Ward 1903, 193. Cf.Compare Zedler $1989,49$.

26. I would like to thank the Gottfried Wilhelm Leibniz Bibliothek-Niedersächsische Landesbibliothek in Hanover for their kind permission in allowing me to publish this passage from the manuscript.

27. The published version of this letter, found in Klopp 1873, $\mathrm{X}$ vol. 9, 145-55 and Gerhardt 1890, 558-65, is in fact an unsent fair copy made from Leibniz's (no longer extant) second draft. The version of the letter which that Leibniz actually sent to Sophie was considerably shorter, and is still unpublished. It is held by the Gottfried Wilhelm Leibniz Bibliothek--Niedersächsische Landesbibliothek in Hanover, under the shelf mark LBr.F 16, B1. 52-3.

28. This is symptomatic of Leibniz's general approach to writing philosophy, which, especially in his correspondence, was generally to reveal as little of his philosophical views as he felt he could get away with.

29. "[Y] Yyou may henceforth consider me as one of your disciples." Leibniz 1923-1923, XVI-vol. 17, 438; Sophie Charlotte to Leibniz (22Aug 22-/4 Sept. 1, 1699).

30. See, for instance, Crousaz 1737, 47.

31. Klopp 1873, IX vol. 9, 115; Sophie to Leibniz, 10-Jan. 10, 1705. See also Elizabeth Burnet's travelogue entry for 19 -September 19,1707 , in which Burnet records details of a conversation with Sophie. Among other things, Burnet notes Sophie's belief that God will not punish anyone eternally. See Burnet's Travelogue, Bodleian Library, Oxford, Rawlinson MS D. 1092, fol. 126v. I would like to thank an anonymous Hypatia referee for bringing this text to my attention.

32. For further information, see Strickland forthcoming. 
33. See Leibniz 1923-1923-, Xvol. 10, 58-62; Leibniz to Sophie (3/13-Sept. 3/13, 1694).

34. "ut fieri solet." In his book Leibniz et les deux Sophies, Foucher de Careil $(1876,53)$ provides a French translation of Molanus's letter to Leibniz, which was originally written in Latin, and for some reason elects to translate Molanus' $\underline{\mathrm{s}}$ "ut fieri solet" [as she is in the habit of doing/as she is accustomed to do] as "comme c'est l'habitude des gens étrangers à ces matières" [as is the habit of people who are unfamiliar with these matters]. Foucher de Careil's French translation is problematic, since it goes beyond what Molanus actually wrote; in his letter to Leibniz, Molanus merely complains that Sophie is by nature somewhat inquisitive and argumentative, but Foucher de Careil's French translation has Molanus say that Sophie's inquisitive and argumentative nature is a result of her ignorance of philosophical matters, which is not-a thought to bethat is not found in the Latin letter which that left Molanus's pen. Such an inaccurate translation does nothing to rescue Sophie from her undeserved reputation as a philosophical incompetent. And- $\underline{\text { Iin }}$ fact $_{2}$ it may have helped to cement it, for in a more recent discussion of Molanus's letter, Beatrice H.-Zedler unfortunately elects to translate not Molanus's Latin but Foucher de Careil's faulty French

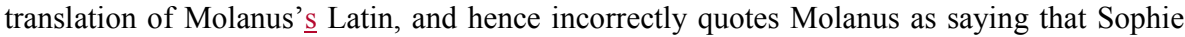
multiplied questions "as is the habit of people who are strangers to these arguments." See Zedler 1989, 49.

35. For a classic treatment of this account, see Locke 1690, II.I.23, II.VIII.4, and II.8.12.; 36. On this, see Balz 1918, 228.

37. See, for example, Locke 1690, I.II.15. This is not to suggest, however, that Sophie was influenced by Locke. As far as I am aware, there is no evidence that she ever read Locke, or that she knew of his philosophy.

\section{REFERENCES}

Anon. 1694. Verhandeling van de helle. Groningen.

Baily, F. E. 1938. Sophia of Hanover and her times. London: Hutchinson \& Co.

Balz, Albert G. A. 1918. Dualism and early modern philosophy II. The Journal of Philosophy, Psychology $y_{2}$ and Scientific Methods 15 (9): 225-41.

Bodemann, Eduard, ed. 1891. Elisabeth Charlotte an Sophie. (2 vols). Hanover: Hahn.

Boëthius. 1697. Consolatio philosophiae. Lüneburg.

Broad, Jacqueline. 2002. Women philosophers of the seventeenth century. Cambridge, UK: Cambridge University Press.

Buchius, Paulus. 1694. Het godlyk weezen. Amsterdam.

Collins, Antony. 1713. A discourse of free-thinking, occasion'd by the rise and growth of a sect call'd free-thinkers. London.

Crousaz, Jean Pierre de. 1737. Examen de l'essai de Mr. Pope sur l'homme. Lausanne.

des Bans, Louis. 1702. L'art de connaître les hommes. Paris.

Fara, Patricia. 2004. Leibniz's women. Endeavour 28 (4): 146-48.

Foucher de Careil, Louis Alexandre. 1876. Leibniz et les deux Sophies. Paris: G. Bailliere.

Foucher de Careil, Louis Alexandre------, ed. 1854. Lettres et opuscules inédits de Leibniz. Paris: Ladrange.

Garber, Daniel and Ayers, Michael, eds. 1998. The Cambridge history of seventeenth-century philosophy. Cambridge, UK: Cambridge University Press.

Gerhardt, C. I., ed. 1890. Die philosophischen schriften von Gottfried Wilhelm Leibniz, vol. 7. Berlin: Weidmann.

Kemble, John M. 1857. State pPapers and çCorrespondence. London: John W. Parker and Sson. 
Kersey, Ethel M. 1989. Women philosophers: A bio-critical source book. London: Greenwood Press.

Klopp, Onno, ed. 1873 (vols. $\forall \amalg \underline{7}, \forall \amalg \amalg$, and $¥ X \underline{9}$; 1877: vol. 10). Die werke von Leibniz. Hanover: Klindworth.

Leibniz, G. W. 1923_-. Sämtliche schriften und briefe reihe I, ed. Akademie der Wissenschaften. (20 volumes). Berlin: Akademie Verlag.

Locke, John. 1690. An essay concerning human understanding. London.

Mates, Benson. 1986. The philosophy of Leibniz. Oxford: Oxford University Press.

Ogilvie, Marilyn Bailey. 1986. Women in science: A biographical dictionary with annotated bibliography. London: MIT Press.

Richardson, Samuel. 1657. A discourse of the torments of hell. London.

Ross, George MacDonald. 1990. Leibniz's exposition of his system to Queen Sophie Charlotte and other ladies. In Leibniz in Berlin, eds. H. Poser and A. Heinekamp. Wiesbaden: Franz Steiner.

Sophie de Hanovre. 1990. Mémoires et lettres de voyage, ed. Dirk van der Cruysse. Paris: Fayard.

Strickland, Lloyd, ed. 2006. The shorter Leibniz texts. London: Continuum.

Strickland, Lloyd. Forthcoming. Leibniz on eternal punishment. British Journal for the History of Philosophy.

Toland, John. 1704. Letters to Serena. London.

Foland, John------ 1705. An account of the courts of Prussia and Hanover; sent to a minister of state in Holland by Mr. Toland. London.

Foland, John. 1704. Letters to Serena. London.

Ward, Adolphus William. 1903. The eElectress Sophia and the Hanoverian succession. London: Goupil \& Co.

Weber, Eugen. 1999. Apocalypses. London: Pimlico.

Zedler, Beatrice H. 1989. The three princesses. Hypatia 4 (1): 28-63. 